ФОРМУВАННЯ ПРОФЕСІЙНОЇ КОМПЕТЕНТНОСТІ Й ОСОБИСТОСТІ МАЙБУТНЬОГО ФАХІВЦЯ З ТЕХНОЛОГІЇ ХАРЧУВАННЯ ЗА УМОВ РЕАЛІЗАЦІї ДУАЛЬНОЇ ФОРМИ ЗДОБУТТЯ ОСВІТИ

\title{
DEVELOPING OF PROFESSIONAL COMPETENCE AND PERSONALITY OF THE FUTURE SPECIALIST IN FOOD TECHNOLOGY UNDER THE CONDITIONS OF REALIZATION OF THE DUAL FORM OF EDUCATION
}

В умовах інтеграційних процесів особливої значущості набувають питання формування професійної компетентності та розвитку особистісних якостей майбутніх фрахівців, зокрема у сорері харчового виробничтва. Ринок праці потребує оновлення та зміни традиційних навчальних підходів до підготовки висококвалісрікованих орахівиів, здатних застосовувати теоретичні знання, практичні вміння й навички в умовах сучасного харчового виробниитва, швидко адаптуватися до потреб потенційних працедавців. Зазначене вимагає модернізації та вдосконалення освітнього прочесу. Сучасна освіта потребує оновлення освітніх форм, здатних забезпечити високий рівень підготовки й мотивації майбутніх фрахівців, їх адаптацію до умов виробництва. Одним з інноваційних підходів до реалізації навчального прочесу виступає дуальна фрорма здобуття освіти. Серед основних завдань ї̈ впровадження визначаємо формування та розвиток професійної компетентності та особистісних якостей майбутніх фрахівців із технології харчування для вирішення прикладних навчальних завдань, подолання невідповідності між теоретичною та практичною підготовкою випускників спеціальності 181 «Харчові технології», посилення співпраці навчальних закладів та підприємств-працедавців. Для реалізації дуального освітнього процесу під час підготовки фрахівців із технології харчування необхідне впровадження низки заходів: пошук суб'єктів господарювання-дуальних партнерів навчальних установ, розроблення положення про організацію освітнього процесу за дуальною формою здобуття освіти, створення методичного забезпечення дуального освітнього процесу, проведення тренінгів, курсів підвищення кваліфікації для кураторів та координатора дуального освітнього процесу.

Розвиток дуальної форми здобуття освіти під час підготовки срахівців із технологіі харчування дасть змогу врахувати вимоги бізнесу та суб'єктів господарювання щодо формування профресійної компетентності випускників закладів освіти, стимулюватиме працедавців до інвестицій у харчову освіту, сприятиме підвищенню мотиваціі здобувачів освіти до отримання просресійних умінь та навичок, розвитку профресійно значущих якостей особистості.

Ключові слова: вища освіта, навчання, дуальна фоорма здобуття освіти, профе- сійна компетентність, майбутні фрахівці з харчових технологій, педагогічні підходи.

In the context of integration processes, the issues of formation of professional competence and development of personal qualities of future specialists, in particular in the field of food production, become especially important. The labor market needs to update and change traditional training approaches to training highly qualified, mobile professionals who are able to apply theoretical knowledge, practical skills, and abilities in modern food production, quickly adapt to the needs of potential employers. This requires modernization and improvement of the educational process. Modern education requires neweducational forms that can provide a high level of training and motivation of future professionals, their adaptation to production conditions. One of the innovative approaches to the implementation of the educational process is a dual form of education. Among the main tasks of its implementation, we determine the formation and development of professional competence and personal qualities of future food technology professionals to solve applied problems, overcoming the discrepancy between theoretical and practical training of graduates of specialty 181 "Food Technology", strengthening cooperation betweeneducational institutions and employers. In order to carry out the dual educational process in the training of specialists in food technology, it is necessary to implement a number of measures: search for business entities-dual partners of educational institutions, development of regulations on the organization of the educational process as for dual form of education, advanced training for facilitators and coordinator of dual educational process.

The development of a dual form of education in the training of food technology specialists will take into account the requirements of business and business entities for the formation of professional competence of graduates, it will encourage employers to invest in food education, and it will increase the motivation of students to acquire professional skills and to develop professionally significant features of a person.

Key words: higher education, training, the dual form of education, professional competency, the future specialists in food technology, instructional techniques.
Постановка проблеми в загальному вигляді. Важливою характеристикою сучасного суспільства $\epsilon$ розвиток соціально значущих якостей особистості, індивідуальних здібностей, умінь та навичок, що здатні задовольнити потреби й запити виробництва та ринку праці. Трансформаційні процеси у суспільному та виробничому середовищі, науково- технічний прогрес спричинили значне збільшення обсягу теоретичних знань, практичних умінь і навичок, які повинні усвідомити й використовувати майбутні фрахівці. У зв'язку із цим перед вищою школою постає завдання підготовки компетентних, висококваліфікованих фрахівців, здатних до успішного професійного становлення, саморозвитку, 
самореалізації, упровадження інноваційних виробничих технологій, збагачення досвіду пізнавальної діяльності.

Харчова промисловість України відноситься до провідних галузей переробної промисловості. Розвиток цієї галузі промисловості залежить не лише від упровадження інноваційних технологій виробництва, а й від кваліфікації та якості підготовки фрахівців. Процес фрормування профресійної компетентності майбутніх фрахівців із технології харчування має базуватися на ціннісних орієнтаціях індивіда, потребі у навчанні й постійному підвищенні рівня власних знань, умінь чи навичок. Одним із напрямів удосконалення процесу підготовки майбутніх фрахівців із технології харчування $€$ впровадження дуальної фрорми здобуття освіти. Реалізація дуальної освіти забезпечить удосконалення механізмів співпраці держави, бізнесу, навчальних закладів та здобувачів освіти, уніфрікує вимоги щодо компетентності випускників із боку закладів освіти та працедавців [18, с. 506-507].

Аналіз останніх досліджень і публікацій. Значний інтерес для нашого наукового дослідження представляють наукові праці Д. Торопова, Н. Матвеева, І. Ушакової, Д. Бауда, Б. Уокмена та ін.

Проблеми фрормування професійної компетентності фрахівців різних профрілів вивчали: О. Джеджула, І. Чемерис, В. Кравець, В. Чайка, Т. Литвин та ін.

Незважаючи на значну кількість наукових праць, присвячених фрормуванню професійної компетентності та особистісних якостей фрахівців різних профілів (Ю. Безпалько, Т. Сулима, Г. Троцко, Н. Кузьміна, С. Кравець, І. Учитель та ін.), методологія означеного процесу залишається дискусійною. Очевидно, що проблема профресійної підготовки фрахівців із технології харчування за умови реалізації дуальної освіти потребує вивчення та уточнення.

Виділення не вирішених раніше частин загальної проблеми. У сучасних умовах особливої актуальності набувають питання підвищення якості освітнього процесу, відповідності професійної підготовки здобувачів освіти вимогам сучасної економіки й ринку праці, запитам потенційних працедавців. Тому дослідження проблеми фрормування професійної компетентності майбутніх фахівців із технології харчування є багатоаспектним та потребує подальшого вивчення.

Мета статті. Мета статті полягає в обґрунтуванні концептуальних засад формування професійної компетентності й особистісних характеристик майбутніх фрахівців із технології харчування за умов реалізації дуальної фрорми здобуття освіти. Для досягнення мети нами було застосовано системний комплекс методів дослідження: теоретичні - аналіз, синтез, узагальнення змісту педагогічної та навчально-методичної літератури 3 метою характеристики особливостей формування професійної компетентності фрахівців із технології харчування; порівняння й абстрагування - для визначення методологічних засад фрормування професійної компетентності майбутніх фрахівців із технології харчування; узагальнення та сuсmематизація - для фрормулювання висновків дослідження.

Виклад основного матеріалу. Входження України в економічний, політичний та правовий простір Європейського Союзу неможливий без рефрормування системи вищої освіти. Модернізація освітнього середовища спрямована на підготовку висококваліфрікованих, конкурентоспроможних фрахівців, здатних швидко адаптуватися до змін харчового виробництва, постійно оновлювати рівень власних професійних знань, умінь і навичок [7, с. 105-106]. Процес професійної підготовки майбутніх фахівців із харчових технологій має базуватися на їхній готовності до виконання певних видів діяльності, потребі особистості у набутті компетентностей, власному саморозвитку та самореалізації протягом життя [5, с. 42-43].

Досвід європейських країн свідчить про важливість інтеграції ринку освітніх послуг та ринку праці для постійного розвитку продуктивних сил, що відповідають потребам суспільства, всебічного розвитку особистості, задоволення її виробничих та інтелектуальних потреб. На думку низки дослідників, інтеграційні процеси в освітньому середовищі є закономірною тенденцією, спрямованою на підвищення якості навчання, посилення його практичної спрямованості, пізнавального та мотиваційного складників, забезпечення працевлаштування випускників навчальних закладів [18, с. 507].

Ефективне поєднання теоретичного та практичного складників освітнього процесу, взаємоузгоджена співпраця навчальних закладів та суб'єктів господарювання можливі за умов реалізації дуальної фрорми здобуття освіти. На думку Н. Світайло, О. Купенко, В. Дементова, досвід підготовки фахівців у різних країнах світу свідчить про інтерес педагогів та науковців до функціонування дуальної освітньої системи. Зокрема, організація дуального навчання $€$ найбільш ефективною та затребуваною для тих спеціальностей, що вимагають високого рівня самоорганізації, мотивації, мобільності й адаптивності фрахівців, сорормованих комунікативних навичок, умінь вирішувати складні виробничі завдання та дії [15, с. 10]. На думку педагогів, дуальна фрорма здобуття освіти вже підтвердила свою ефективність в умовах сучасного навчання та виробничої діяльності майбутніх фрахівців. Її впровадження забезпечує постійну модернізацію та оновлення змісту освіти, підвищення рівня конкурентоспроможності та працевлаштування молоді, адаптацію до першого робочого місця, створює належні умови для 
підготовки кваліфрікованих кадрів відповідно до запитів конкретних підприємств та тенденцій на ринку праці, полегшення пошуку молодих талановитих фрахівців [15, с. 10-13].

Процес профресійної підготовки фрахівців із технології харчування на засадах дуальності вимагає дослідження різноманітних аспектів орормування їхньої професійної компетентності. Ефективність набутих знань і вмінь, фрормування ціннісного ставлення до навчання, соціальна й професійна мобільність студентів стали основою для осмислення компетентнісного підходу до сучасної освіти [6, с. 40-41]. Цей підхід відображає зміст освітнього процесу, що включає не лише знаннєво-орієнтований компонент, а й ціннісне ставлення до набутих знань та вмінь, що є основою для саморозвитку та самореалізації особистості [9, с. 2-3].

Реалізація компетентнісного підходу передбачає набуття цілісного досвіду вирішення життєвих і професійних завдань та проблем, виконання ключових фрункцій і соціальних ролей [10, с. 232-233]. Досліджуючи компетентнісний підхід, науковці розглядають його також у контексті ідей цілеспрямованості освітнього процесу, при цьому зміст навчання визначається через сукупність знань та вмінь студентів, досвід творчої діяльності, ціннісне ставлення до майбутньої профресії [10, с. 234], ієрархічність освітніх компетентностей, що безпосередньо впливають на відбір змісту, організаційних фрорм, технологій навчання [17, с. 283-284]. Уважаємо, що компетентнісний підхід визначає всебічну підготовку індивіда не лише як кваліфікованого фрахівця, профресіонала своєї справи, а й як усебічно розвиненої особистості, сприяє фрормуванню профресійних компетентностей, необхідних та затребуваних на ринку праці, дає змогу ідентифікувати й оцінити виробничі завдання, проблеми профресійної діяльності у різних контекстах уже під час навчання [8, с. 15-16].

Сутність дуального навчання за умови реалізації компетентнісного підходу полягає у вдосконаленні підготовки здобувачів освіти під час виконання виробничих дій та операцій на базі суб'єктів господарювання, посиленні практичного складника навчання, що сприяє розвиткові відповідних компетентностей спеціалістів.

Термін «компетентність» - загальнонауковий та зустрічається у вітчизняних і зарубіжних дослідженнях із фрілософії, педагогіки, психології, маркетингу, економіки, менеджменту тощо. В освіті ця десініція з'явилася порівняно недавно для оцінки рівня професійної підготовки та характеристики аспектів її реалізації. Незважаючи на розповсюдження терміна «компетентність», у сучасних дослідників не існує єдиної думки щодо його сутності, змісту, характеристик. Зокрема, «компетентність» трактують як систему знань, умінь, здібностей, необхідних для реалізації професійної діяльності [2, с. 75; 12, с. 230-231]; готовність до розв'язання профресійних завдань чи проблем, спроможність до самореалізації [16, с. 52-54; 17, с. 284]

Погоджуючись із думкою Н. Бібік, уважаємо дефрініцію «компетентність» оцінною категорією, що визначає результативність професійної діяльності людини, її здатність до виконання виробничих завдань та фрункцій [1, с. 47-49].

Профресійна компетентність розглядається сучасними дослідниками як наукове й практичне структурування знань, що сприяють кращому виконанню виробничих завдань. Дослідники Л. Єршова, Г. Ковальчук розглядають «прооресійну компетентність» як сукупність індивідуальних якостей особистості, її знань, умінь та навичок, що забезпечують успішну реалізацію професійних обов'язків і фрункцій, високу продуктивність виробничої діяльності [3, с. 163-164; 4, с. 99]. Суголосним цьому $є$ твердження О. Мазур, яка під дефініцією «професійна компетентність» розуміє ставлення людини до професійної діяльності, що сприяє її результативності, досягненню успіхів [11, с. 66-67]. Більш детальний аналіз цього терміна дав змогу виокремити у змісті професійної компетентності теоретичні знання, аналітичні та комунікативні здібності, практичні вміння та навички, що забезпечують відповідність фрахівця вимогам профресії, спеціальності й застосовуються відповідно до певної виробничої ситуації [6, с. 7-9; 13 , с. 52-53].

Успішне виконання завдань професійної діяльності, значні кількісні та якісні результати праці також пов'язані з досягненням випускниками закладів освіти професіоналізму у власній діяльності. Досягнення високого професійного рівня потребує розвитку відповідних якостей особистості та здібностей спеціалістів, широкого спектру знань та вмінь, загальної та професійної культури, спрямованості на творчу самореалізацію. Тобто сучасне розуміння фрахівця 3 технології харчування як професіонала включає сукупність особистісно-професійних якостей, усвідомлення себе як творчої, мобільної, креативної особистості, достатній рівень сорормованості професійної культури, саморозвитку й самосвідомості, стійку мотивацію до виконання виробничих завдань та розв'язання проблем діяльності [14, с. 151]. При цьому результат освітньої підготовки студентів передбачає сорормованість компетентностей (дуальних, інтегральних, загальних, фрахових). Охарактеризуємо кожну 3 визначених компетентностей.

Дуальні компетентності передбачають застосування теоретичних знань і методів харчових технологій під час навчання на базі суб'єктів господарювання. Інтегральні - окреслюють здат- 
ність до комплексного розв'язання практичних завдань чи проблем технічного й технологічного характеру. Загальні компетентності визначають здатність виявляти ініціативу та підприємливість, генерувати нові ідеї, оцінювати й забезпечувати якість виконуваних робіт, здатність до системного мислення, пошуку, обробки, синтезу, аналізу інформації, застосування знань у різноманітних робочих ситуаціях. Фахові компетентності передбачають опанування базових знань зі стандартизації, метрології, сертифікації, охорони праці для забезпечення високої якості виробництва харчової продукції, здатність до запровадження у виробництво нових технологій харчових продуктів, підвищення ефрективності харчового виробництва, удосконалення асортименту продукції, здатність організовувати й проводити контроль якості, безпечності харчової продукції, застосування типових алгоритмів виробничої діяльності та навички роботи із сучасною технікою чи обладнанням [5, с. 43-44].

Сукупність визначених компетентностей відображає рівень сфрормованості професійної компетентності, підготовленість молодих фрахівців до виробничих реалій, рівень володіння методами й засобами професійної діяльності, вміння застосовувати отримані теоретичні знання та практичні навички, прагнення до постійного розвитку й удосконалення, відповідність запитам ринку праці. Серед чинників професійної компетентності виокремлюємо когнітивний, мотиваційний, операційний, поведінковий, що надають індивідуального характеру виробничій діяльності фрахівця. Професійна культура фрахівця $€$ основою для фрормування індивідуальної траєкторії та стратегії виконання виробничих завдань. Серед важливих складників професійної культури фахівців із харчових технологій виокремлюємо: системний світогляд, предметні знання, вміння та навички, інфрормаційну культуру, професійно-творчу діяльність та профресійно-особистісний розвиток.

Слід зазначити, що дієвою формою організації освітнього процесу під час підготовки фахівців із харчових технологій є дуальна. Вона інтегрує різні види дисциплін, теоретичний та практичний зміст навчання, максимально наближує освітній процес до виробничих реалій та вирішує завдання формування професійної компетентності майбутніх фрахівців [18, с. 509].

Висновки. Професійна компетентність майбутніх фрахівців із технології харчування $€$ системним, інтегративним поняттям, що поєднує різноманітні компетентності й професійно-значущі якостей особистості, необхідні для результативного виконання виробничих дій, операцій, вирішення технологічних завдань та проблем. Серед складників професійної компетентності майбутніх фрахівців із харчових технологій виокремлюємо дуальні, інтегральні, загальні, фрахові компетентності. Готовність випускників навчальних установ до виконання завдань професійної діяльності визначаємо як професіоналізм. Основою для реалізації творчого потенціалу й фрормування особистості майбутнього фахівця з технології харчування вважаємо профресійну культуру. Підвищення якості профресійної підготовки майбутніх фрахівців пов'язуємо 3 реалізацією дуальної форми здобуття освіти.

\section{БІБЛІОГРАФІЧНИЙ СПИСОК:}

1. Бібік Н.М. Компетентнісний підхід: рефрлексивний аналіз застосування. Компетентнісний підхід у сучасній освіті: світовий досвід та українські перспективи. Київ : К.І.С., 2004. С. 47-52.

2. Васильев И.Б. Методологические основы системно-компетентностного похода в профорбазовании. Алматы : АГТУ, 2008. 76 с.

3. Єршова Л. Трансорормація системи цінностей учнівської і студентської молоді в контексті рефрормування системи вітчизняної професійної освіти. Науковий вісник Інституту профресійно-технічної освіти НАПН України. Профресійна педагогіка. 2018. № 16. С. 162-168.

4. Ковальчук Г.О. Формування профресійних педагогічних умінь майбутніх викладачів педагогіки. Педагогіка і психологія. 2011. № 1. С. 98-103.

5. Кравець С.Г. Ключові компетентності в оновленні змісту професійної підготовки фрахівців ресторанного сервісу. Науковий вісник Інституту профресійно-технічної освіти НАПН України. Профресійна педагогіка. 2003. Вип. 6. С. 40-46.

6. Краевский В.В., Хуторской А.В. Предметное и общепредметное в образовательных стандартах. Педагогика. 2003. С. 3-10.

7. Красильникова В.А. Методология создание единой информационно-образовательной среды университетского округа. Вестник ОГУ. 2002. C. $105-110$.

8. Лапина Г.Л. Критерии оценки деятельности студентов. Специалист. 1997. № 3. С. 14-16.

9. Луговий В.І. Запровадження компетентнісного підходу у вищій освіті - вимога часу. Міжнародна виставка «Сучасні навчальні заклади - 2010» : офріц. каталог виставки. Київ, 2010. 8 с.

10. Стандартизація професійної освіти на основі компетентнісного підходу / П.Г. Лузан та ін. Science Rise. 2018. № 5(25). С. 32-35.

11. Мазур О.Л. Формування професійної компетентності педагогів. Директор школи. № 9(81). C. $64-67$

12. Астахова В.И., Михайлева Е.Г., Астахова Е.В. Непрерывное образование в контексте образовательных реформ в Украине : монография. Харків : HУA, 2006. 299 c.

13. Овчарук О.В. Компетентності як ключ до оновлення змісту освіти. Стратегія рефрормування освіти в Україні: рекомендації з освітньої стратегії. Київ : К.І.С. С. 51-53.

14. Пінаєва О.Ю Інформатизація освіти та її застосування в навчальному процесі. Актуальні проблеми 
трудової і професійної підготовки молоді. 2004. Вип. 10. С. 150-151.

15. Світайло Н., Купенко О., Дементов В. Принципи організаційного та методичного забезпечення практичної складової в рамках реалізації дуальної моделі освіти (старт в умовах багатьох невизначеностей) : навчально-методичний посібник. Суми : СумДУ. 133 с.

16. Хуторський А.В. Ключевые компетенции: технология конструирования. Народное образование. 2003. № 5. C. 55-61.
17. Ягупов В., Півень Н. Компетентнісний підхід до формування змісту професійної підготовки майбутніх бакалаврів технічного профрілю (на прикладі спеціальності «Інженерне матеріалознавство». Наукові записки Тернопільського національного педагогічного університету ім. В. Гнатюка. Серія «Педагогіка». 2009. Спецвипуск. С. 283-287.

18. Яковчук О.Л. Модель фрормування профресійної компетентності майбутніх техніків-технологів з технології харчування в процесі вивчення хімічних дисциплін у коледжі. Молодий вчений. 2017. № 4. С. 506-509. 